\title{
Development and Validation of the Job Satisfaction Brief Scale
}

\section{Desarrollo y Validación de la Escala Breve de Satisfacción Laboral}

\section{Ernesto Rosario-Hernández ${ }^{1}$, Lillian V. Rovira-Millán ${ }^{2}$, \& Rafael A. Blanco-Rovira ${ }^{3}$}

1 School of Behavioral and Brain Sciences, Ponce Health Sciences University; Ponce Research Institute, Ponce Health Sciences University. (D) https://orcid.org/0000-0002-2523-6162

2 University of Puerto Rico, Cayey Campus, Puerto Rico. (D) https://orcid.org/0000-0001-7479-7401

3 Carlos Albizu University, San Juan Campus, Puerto Rico. (D) https://orcid.org/0000-0002-8153-1967

* Correspondence: Dr. Ernesto Rosario-Hernández, erosario@psm.edu; Postal address: School of Behavioral \& Brain Sciences, Clinical Psychology Programs, Ponce Health Sciences University, PO Box 7004, Ponce, Puerto Rico, 00732-7004.

Recibido: 16 diciembre 2021 | Aceptado: 16 enero 2022 | Publicado: 26 enero 2022

\section{WWW.REVISTACARIBENADEPSICOLOGIA.COM}

\section{Cite as:}

Rosario-Hernández, E., Rovira-Millán, L. V., \& Blanco-Rovira, R. A. (2022). Development and validation of the Job Satisfaction Brief Scale. Revista Caribeña de Psicología, 6, e6191. https://doi.org/10.37226/rcp.v6i1.6191

\begin{abstract}
This research aimed to develop and validate an instrument to measure job satisfaction in general. A total of 1,491 employed people who worked at least 20 hours per week and were 21 years of age or older participated in the study. The Job Satisfaction Brief Scale was developed with a total of eight items. Several exploratory factor analyses and several confirmatory factor analyses were performed using structural equation modeling to examine the scale's internal structure. The final version of the scale was composed of four items for which Cronbach's alpha and McDonald's omega coefficients were examined and fluctuated between .77 to .78 . The results of the factor analyses, especially the confirmatory one, support the one-dimensional internal structure. The new scale appears to be invariance among gender, age, job position, and type of organization. In this way, the results provide evidence of the validity and reliability of the instrument created to measure job satisfaction in general.
\end{abstract}

Keywords: confirmatory factor analysis, exploratory factor analysis, internal structure, job satisfaction, measurement invariance, psychometric properties

\section{RESUMEN}

El propósito de esta investigación fue desarrollar y validar un instrumento para medir la satisfacción laboral en general. Participaron en el estudio un total de 1.491 personas empleadas que trabajaban al menos 20 horas a la semana y tenían 21 años de edad o más. Se elaboró la Escala Breve de Satisfacción Laboral con un total de ocho ítems. Se realizaron varios análisis factoriales exploratorios y varios análisis factoriales confirmatorios utilizando modelos de ecuaciones estructurales para examinar la estructura interna de la escala. La versión final de la escala estuvo compuesta por cuatro ítems para los cuales se examinaron los coeficientes alfa de Cronbach y omega de McDonald y fluctuaron entre .77 y .78. Los resultados de los análisis factoriales, especialmente el confirmatorio, 
sustentan la estructura interna unidimensional. La nueva escala parece ser invariante por género, edad, puesto de trabajo y tipo de organización. De esta forma, los resultados aportan evidencia de la validez y confiabilidad del instrumento creado para medir la satisfacción laboral en general.

Palabras Claves: análisis de factores exploratorio, análisis de factores confirmatorio, estructura interna, invarianza de medición, propiedades psicométricas, satisfacción laboral

\section{INTRODUCTION}

Job satisfaction is the most researched organizational variable in industrial and organizational psychology (Spector, 1997). Job satisfaction, according to Spector, is how people feel about their work and various aspects of their jobs. As a result, job satisfaction is seen as an attitude variable, and therefore, job satisfaction is one of the most critical attitudes in organizations (Bright, 2021). Thus, Spector (1997) defines job satisfaction as a global feeling about the job or a related constellation of attitudes about various aspects of the job.

Low job satisfaction can have several negative consequences in organizations, such as poor job performance, higher turnover intention, higher absenteeism, burnout, and poor physical and psychological health (e.g., Begley \& Czajka, 1993; Carsten \& Spector, 1987; Johns, 1997; Judge et al., 2001; Lambert et al., 2001; Lee \& Ashforth, 1993; Lum et al., 1998; Michaels \& Spector, 1982; Mobley, 1977). Also, job satisfaction has served as a mediator, for example, between exposure to workplace bullying and turnover intention (e.g., Rosario-Hernández et al., 2018). Therefore, measuring job satisfaction is necessary to understand better the relationship between several organizational variables in which job satisfaction tends to be a central theme.

However, most of the job satisfaction measures used in Puerto Rico and Latin America have been translated into Spanish from other languages. They have been initially validated for other people working in other countries. Moreover, most of these translated scales tend to be long and with several facets, such as the Job Satisfaction Survey (Spector, 1985) and the Job Descriptive Index (Smith et al., 1969), which have been used frequently in Puerto Rico by researchers. Nevertheless, these instruments have served well in our settings; however, we need to develop and validate shorter and more appropriate instruments for our working population.
Researchers in industrial and organizational psychology and human resources management will benefit from having available a shorter instrument to measure job satisfaction in general for their studies. Therefore, the current study aims to develop and validate a job satisfaction brief scale for the working population of organizations in Puerto Rico.

\section{Measurement Instruments of Job Satisfaction}

Commonly, job satisfaction is measured using validated questionnaires because it is an easy way to do so (Spector, 1997). Thus, several well-recognized measures in I/O psychology measure job satisfaction through various facets, such as the Job Descriptive Index (JDI; Smith et al., 1969), the Minnesota Satisfaction Questionnaire (MSQ; Weiss et al., 1967), the Job Diagnostic Survey (JDS; Hackman \& Oldman, 1975), and the Job Satisfaction Survey (JSS; Spector, 1985). These questionnaires measure different aspects of job satisfaction, such as satisfaction with co-workers, supervision, and pay, among others. Some questionnaires generally measure job satisfaction, and examples of these are the Job in General Scale (JIG; Ironson et al., 1989) and a subscale of the Organizational Assessment Questionnaire (Michigan Organizational Assessment Questionnaire), MOAQ; Cammann et al., 1979), which measures overall job satisfaction with three items.

Apart from the latter, the other scales have several facets and therefore a large number of items, which makes it a bit complicated to have to administer them when used in an investigation in which other variables are also intended to be measured, causing the participants to take a long time to answer the questionnaires and thus increasing the number of these that abruptly ends their participation in the study and especially when it is answered online.

\section{Framework for the Scale}

Muchinsky (2012) defines job satisfaction as an employee's level of happiness due to his or her work. 
According to Hulin and Judge (2003), an employee's affective reaction to a job is based on comparing the job's actual and predicted outcomes. According to Dawis (2004), job satisfaction varies depending on the time and conditions. What is important to various people varies, and what is essential to the same person may alter. Because work is one of the most critical aspects of our lives, employee job satisfaction, as a result, relates to how employees feel about their current work responsibilities; it is an emotional response triggered by the employee's function in the organization (Eksan, 2019). Job satisfaction is an affective reaction to work and indicates that the employee has a positive job attitude (Zhang \& Li, 2020). Therefore, we intended to develop a brief scale to measure job satisfaction that includes the attitudinal and affective aspects of the construct as well as it might serve as an indicator of job-related well-being, which is an argument proposed by some of the literature (e.g., Häusser et al., 2010; van der Doef \& Maes, 1999). Thus, we define job satisfaction as the positive emotions that arise when doing our work, leading us to a sense of work-related well-being.

\section{Objectives of the Study}

Thus, the aims that guided the current study were as follows. First, to develop a brief measurement instrument of job satisfaction using exploratory and confirmatory factor analyses. Second, to examine the convergent and divergent validity of the brief scale via the correlation with other relevant constructs. Third, to examine the reliability of the brief scale via internal consistency using Cronbach's alpha and McDonald's omega with their respective confidence intervals and their descriptive statistics. Finally, to examine the measurement invariance of the final version of the Job Satisfaction Brief Scale by gender, age, job position, type of organization, and type of contract.

\section{METHOD}

\section{Participants}

A total of 1,491 employed individuals from different organizations in Puerto Rico participated in this cross-sectional research design. They were selected based on availability, and their voluntariness, anonymity, and the right to abandon the investigation were guaranteed when they considered it necessary.
Table 1 shows the description of the sample's sociodemographic characteristics, such as, for example, $57.3 \%$ (855) of the people were female, $49.0 \%$ (731) were married, and $55.9 \%$ (834) was between $31-50$ years of age, which can be considered to be in the prime of their careers. The average education achieved was equal to 15.68 , with a standard deviation equal to 2.20 , equivalent to a little more than three years of university. On the other hand, $18.4 \%$ (275) of the participants held a managerial position, $78.6 \%(1,172)$ had a tenure, $56.2 \%(838)$ of the sample worked for the private sector, and finally, $74.3 \%$ $(1,108)$ worked the shift during the day.

\section{Measures}

First, a sociodemographic data sheet was developed and used for the current study. With this, information was collected from the participants related to gender, age, marital status, and other variables to describe the sample of the present study.

Job Satisfaction. The Job Satisfaction Brief Scale was developed on a Likert scale due to its easy construction (DeVellis, 2017). The initial scale consisted of eight items that are answered in a Likert scale format that ranges from "Totally Disagree" to "Totally Agree" on a numerical continuum from '1' to '6.' An item example is: "I feel satisfied with my work."

Work Engagement. We used the Utreacht Work Engagement (UWES; Schaufeli \& Bakker, 2003; Schaufeli et al., 2002). The UWES comprises 17 items measured on a seven-point Likert scale anchored by the response options' $0^{\prime}=$ never and ' 6 ' = always. Six items comprised the vigor subscale (e.g., "At my work, I feel bursting with energy). The Dedication subscale was measured with five items (e.g., "I find the work that I do full of meaning and purpose"). Finally, the remaining six items comprised the absorption subscale has been reported to fluctuate within .82 to .93 (Schaufeli \& Bakker, 2003). Using Cronbach's alpha techniques, the reliability of the UWES and its subscales has been reported between .82 to .93 (Schaufeli \& Bakker, 2003). Several studies carried out in Puerto Rico have used it with samples of employed people, and its results support the internal structure, and its reliability coefficients fluctuated between .81 to .95 using the Cronbach alpha and omega technique (e.g., MartínezAlvarado et al., 2017; Rodríguez Montalban et al., 2011; Rosario-Hernández et al., 2021). For the current 
Table 1

Sociodemographic characteristics of the participants.

\begin{tabular}{|c|c|c|c|c|c|}
\hline Variable & $f$ & $\%$ & Variable & $f$ & $\%$ \\
\hline Gender & & & Work Shift & & \\
\hline Male & 571 & 38.3 & During the Day & 1,108 & 74.3 \\
\hline Female & 855 & 57.3 & During the Afternoon & 76 & 5.1 \\
\hline Age (in years) & & & During the Night & 12 & 0.8 \\
\hline 21-30 (Early Career) & 341 & 22.9 & Rotative & 287 & 19.2 \\
\hline 31-50 (Prime of Career) & 834 & 55.9 & Time Working & & \\
\hline$\geq 51$ (Past Peak of Career) & 316 & 21.2 & 1 month -5 years & 378 & 25.4 \\
\hline Marital Status & & & $6-10$ years & 218 & 14.6 \\
\hline Single & 451 & 30.2 & $11-15$ years & 242 & 16.2 \\
\hline Married & 731 & 49.0 & $16-20$ years & 239 & 16.0 \\
\hline Divorced & 26 & 1.7 & $21-25$ years & 191 & 12.8 \\
\hline Widowed & 154 & 10.3 & $26-30$ years & 127 & 8.5 \\
\hline Living Together & 113 & 7.6 & $\geq 31$ years & 88 & 5.9 \\
\hline Job Position & & & Samples & & \\
\hline Managerial & 275 & 18.4 & Calibration & & \\
\hline Non-Managerial & 1,172 & 78.6 & Sample $1\left(\mathrm{n}_{1}\right)$ & 358 & 24.0 \\
\hline Work Contract & & & Sample $2\left(\mathrm{n}_{2}\right)$ & 364 & 24.4 \\
\hline Permanent/Tenure & 1,172 & 78.6 & Validation & & \\
\hline Temporary & 310 & 20.8 & Sample $3\left(\mathrm{n}_{3}\right)$ & 387 & 26.0 \\
\hline Type of Organization & & & Sample $4\left(n_{4}\right)$ & 382 & 25.6 \\
\hline Public & 621 & 41.6 & & $\mathbf{M}$ & SD \\
\hline Private & 838 & 56.2 & Education & 15.68 & 2.20 \\
\hline
\end{tabular}

Note. $n=1,491 ; M=$ Mean, $S D=$ Standard Deviation.

study, we used the UWES short form, which comprises nine items, three items for each subscale. Thus, we tested a three-dimension model using weight least squares "WLSMV" estimator, $\chi 2(86)=2,556, \mathrm{CFI}=$ $.949, \mathrm{TLI}=.938, \mathrm{SRMR}=.102, \mathrm{RMSEA}=.139[.134$, .144]. Reliability was estimated using Cronbach's alpha and McDonald's omega $(\alpha=.865,95 \%$ CI [.844, $.882], \propto=.919,95 \%$ CI $[.911, .926], \propto=.773,95 \% \mathrm{CI}$ $[.753, .790] ; \omega=.863,95 \%$ CI $[.843, .880], \omega=.918,95 \%$ CI $[.910, .926]$, and $\omega=.783,95 \%$ CI $[.763, .803]$ for vigor, dedication, and absorption subscales, respectively.

Burnout. We used the Maslach Burnout Inventory - General Scale (MBI-GS; Maslach et al., 1996) to measure burnout. The MBI uses a 7-point frequency scale (ranging from 0-never to 6-daily) to indicate the extent to which they experienced each item. The emotional exhaustion and cynicism have five items each and the professional efficacy six items. We tested a three-dimension model using weight least squares "WLSMV" estimator, $\chi^{2}(86)=2,556, \mathrm{CFI}=.949$, TLI = .938, SRMR $=.102$, RMSEA $=.139$ [.134; .144]. Reliability was estimated using Cronbach's alpha and McDonald's omega $(\alpha=.865,95 \%$ CI $[.844, .882], \propto=$ $.919,95 \%$ CI $[.911, .926], \propto=.773,95 \%$ CI $[.753, .790]$, $\omega=.863,95 \%$ CI $[.843, .880], \omega=.918,95 \%$ CI [.910, $.926]$, and $\omega=.783,95 \%$ CI $[.763, .803]$ for professional efficacy, emotional exhaustion, and cynicism subscales, respectively.

Turnover Intention. We used the Turnover intention Scale developed by Rosario-Hernández and Rovira-Millán (2018). This is a seven-item instrument in a Likert-agreement response format ranging from ' 1 ' (Totally Disagree) to '6' (Totally Agree), which pretends to measure employee's turnover intention. An item example is: "If a good job opportunity appears, I would not hesitate to accept it." Cronbach's alpha was reported as $\alpha=.91$ and in terms of its 
validity, factor analysis results suggest an internal structure of one-dimension. We examine a one factor structure using weight least squares "WLSMV" estimator, $\chi^{2}(14)=1,074, \mathrm{CFI}=.964$, TLI $=.946$, SRMR=.069, RMSEA $=.225[.214 ; .237]$, reliability was estimated using Cronbach's alpha $(\propto=.913,95 \%$ CI $[.905, .920]$ and McDonald's omega $(\omega=.912,95 \%$ CI $[.905, .920]$.

Social Desirability. We used the Social Desirability Scale developed by Rosario-Hernández and Rovira-Millán (2002). This is an 11-items instrument in a Likert-agreement response format ranging from ' 1 ' (Totally Disagree) to ' 6 ' (Totally Agree), which pretend to measure a response bias in which people respond to a test thinking what is acceptable socially. Authors report its internal consistency through Cronbach's alpha to be .86 , an excellent reliability coefficient. Factor analysis results suggest that the Social Desirability Scale internal structure has only one factor. As part of the current study, we examined the internal structure of the Social Desirability Scale using "WLSMV" and results support a one-factor structure as reported by its authors, $\chi^{2}(44)=2,496, \mathrm{CFI}=$ $.966, \mathrm{TLI}=.958, \mathrm{SRMR}=.067, \mathrm{RMSEA}=.193[.187$, .200]. Also, reliability was estimated and its 95-confidence interval via Cronbach's alpha and McDonald's omega $(\propto=.944,95 \%$ CI $[.939, .950], \omega=.943,95 \%$ CI $[.937, .948])$.

\section{Procedures}

First, authorization to carry out the research was requested from the Institutional Review Board of Ponce Health Sciences University. It was approved, and the protocol number is 160208-ER.

For the construction of the Job Satisfaction Brief Scale, eight items were developed. Then the scale was administered to a total sample of 1,491 people employed in different organizations in Puerto Rico. The data were first analyzed with the IBM-SPSS version 28.0 program, and descriptive statistics, correlation, item analysis, reliability, and exploratory factor analysis were performed. In addition, we used the "lavaan" package of the R3.6.3 program (Rosseel, 2012) to perform the confirmatory factors analyses and invariance testing by gender, age, job position, type of company, and type of contract.
First, we performed descriptive statistics analyses to obtain sociodemographic characteristics of the sample. Also, we conducted descriptive analyzes of the scale's items, such as the mean, standard deviation, skewness, kurtosis, and the minimum and maximum values. An item analysis was also performed to obtain the discrimination index, known as "item-total correlation" or "rbis". We used the whole sample to perform these descriptive and item analyses.

Second, the total sample was randomly split into two samples, calibration, and validation. Then each of them was also randomly split into two more samples; each hereafter referred to as sample 1 (n1), sample 2 (n2), sample 3 (n3), and sample 4 (n4). Third, exploratory factor analyses (EFA) were conducted with sample 1 and sample 2 using SPSS v.28 (IBM, 2021). EFA was conducted using the extraction method of "principal axis factoring" and "direct oblimin" rotation. As selection criteria, all those items that obtained a factor loading $\geq .30$ in the factor to which it supposedly belongs and less than .30 in the other factors were selected, as recommended by Kline (1994).

Fourth, all items selected from the EFA were subjected to confirmatory factor analyses (CFA) using the structural equation modeling to confirm the one-dimensional internal structure of the Job Satisfaction Brief Scale using the weighted least squares-mean and variance adjusted (WLSMV) estimator with the "lavaan" package of the R3.6.3 program, which robustly deals with potentially non-normal data and items are treated as ordinal (Li, 2016a, 2016b). To evaluate the results of the CFA, several fit indices of the structural equation models were used. Kline (2016) recommends using at least four fit indices, although more can be reported. One of the indices that are reported is Chi-Square $(\chi 2)$. This is a fundamental index of absolute adjustment, and it is the same one used when you want to examine the association between nominal variables. However, the crucial difference when used as an index of fit in the structural equations model is that the researcher looks for no differences between the matrices to support that the tested model is representative of the data (Hair et al., 2019).

Given that the $\chi 2$ is sensitive to the sample size and therefore the probability of rejecting the hypothesized model increases when the sample size 
increases, it is recommended to consider other indices (Marsh et al., 1996). In this way, the Root Mean Square Error of Approximation (RMSEA; Byrne, 2016; Hu \& Bentler, 1999) was used, values ranging from .08 to .10 are considered as mediocre, less than .08 for the RMSEA indicate an acceptable fit, while values equal to .05 or less indicate a good fit of the model (Browne \& Cudeck, 1993; MacCallum et al., 1996). In addition, Standardized Square Root Mean Residual (SRMR; Hu \& Bentler, 1995) was used, which examines the average difference between predicted and observed variances and covariances based on the residual standard error. The lower the SRMR, the better the model's fit, and to consider an acceptable model, it must be equal to or less than .05. On the other hand, the Bentler Comparative Fit Index (CFI) was used as a high fit index to compare the theoretical model with the null model, which assumes that the latent variables of the model do not correlate with each other and values greater than .90 are considered acceptable (Hair et al., 2019). Another increased adjustment index is the Tucker-Lewis Index (TLI). It reflects the proportion in which the theoretical model improves the adjustment concerning the null model (Littlewood Zimmerman \& Bernal García, 2011; Tucker \& Lewis, 1973). Values greater than .90 are considered acceptable. We conducted CFA's with samples 3 and 4 .

Fifth, we recombined the samples and performed descriptive, reliability, and correlation analyses for the Job Satisfaction Brief Scale to estimate means, standard deviation, internal consistency via Cronbach's alpha and McDonald's omega, standard error of measurement, and 95\% confidence interval for the scale. Also, we examined the convergent and divergent validity of the Job Satisfaction Brief Scale by correlating it to other supposedly similar and different constructs.

Finally, we used the recombined sample to assess measuring invariance across gender, age, job position, organization type, and contract type. We tested configural invariance, metric invariance, scalar invariance, and error invariance (or strict invariance) as suggested by some literature (e.g., Byrne, 2016; Muthén \& Muthén, 1998-2012; Wang \& Wang, 2012). We conducted hierarchical tests for invariance of measurement parameters. First, we examined the configured invariance model or pattern invariance, which imposes no equality restrictions on model parameters. This is necessary for testing invariance by comparing it with other models based on fit indices. Second, we examined the weak invariance model or metric invariance. In this model, the factor loadings are treated as invariant across groups. This ensures that the measures are on the same scale across groups for making valid comparisons. Third, we examined the strong invariance model. This model imposes invariance on both factor loadings and item intercept across groups. This is to ensure the underlying factors can be compared across groups. Fourth, we examined the strict invariance model, which requires the factor loadings, intercepts, and residual variances to be invariant. This is to examine whether the variances of the regression equations for each item are invariant across groups. We capitalized on fit index differences for CFI and RMSEA (i.e., $\triangle$ CFI $\leq-.01, \triangle$ RMSEA $\geq .015$ ) reference points as recommended by Cheung (2007), who found in a Monte Carlo study that these indices were equally sensitive to all types of invariances. Notably, as the $\chi 2$ is known to be highly influenced by the sample size (e.g., Rigdon, 1995), it was reported but not considered as a fit index for the invariance testing.

\section{RESULTS}

First, we conducted descriptive statistics and item analysis of the eight items of the Job Satisfaction Brief Scale. Table 2 shows the mean, standard deviation, skewness, kurtosis, and item-total correlations (rbis). Only item 1 did not reach a rbis of .30. However, it was included in the next phase of exploratory factor analysis because it was near the standard threshold used of $r_{b i s}=.30$.

Table 2

Descriptive statistics for original items of the Job Satisfaction Brief Scale in total sample.

\begin{tabular}{lccccccc}
\hline & $\bar{X}$ & SD & $\begin{array}{c}\text { Skew- } \\
\text { ness }\end{array}$ & $\begin{array}{c}\text { Kur- } \\
\text { tosis }\end{array}$ & Min. & $\begin{array}{c}\text { Ma } \\
\text { x. }\end{array}$ & rbis \\
\hline JS-1 & 4.73 & 1.66 & -.1 .039 & -0.242 & 1 & 6 & .27 \\
JS-2 & 4.88 & 1.51 & -.1317 & 0.669 & 1 & 6 & .58 \\
JS-3 & 4.81 & 1.61 & -1.156 & 0.043 & 1 & 6 & .52 \\
JS-4 & 4.91 & 1.52 & -1.250 & 0.378 & 1 & 6 & .62 \\
JS-5 & 5.01 & 1.40 & -1.446 & 1.175 & 1 & 6 & .60 \\
JS-6 & 4.80 & 1.62 & -1.131 & -0.011 & 1 & 6 & .62 \\
JS-7 & 4.09 & 1.67 & -0.475 & -0.936 & 1 & 6 & .32 \\
JS-8 & 4.96 & 1.37 & -1.284 & 0.785 & 1 & 6 & .62 \\
\hline
\end{tabular}

Note. $n=1,491$. 


\section{Exploratory Factor Analyses (EFA)}

We conducted a first EFA with base sample 1, and results of this first iteration showed a two-factor structure for the Job Satisfaction Brief Scale, and these two factors explain a total of $49.66 \%$ of the variance. Items $2,5,7$, and 8 , which are the positive wording items, loaded on factor 1 ; meanwhile, items $1,3,4$, and 6 , which are the negative wording items, loaded on factor 2; moreover, all factor loadings were greater than .30 as suggested by some of the literature (Kline, 1994). According to scholars like Hankins (2008), multi-factor models are only a byproduct of including positive and negative items in the questionnaire; hence the factorial structure of the Job Satisfaction Brief Scale could be related to underlying method effects since the inclusion of both sorts of items has been widely advocated in test construction textbooks (e.g., Spector, 1992) to lower a variety of response biases, such as acquiescence, disacquiescence, and midpoint response styles. However, psychometric research has demonstrated that this mix of items can lead to a false factorial distinction, in which the load of the positive items on one factor and the negative wording one's load on another (e.g., Schmitt \& Stults, 1985). Therefore, in the second iteration, we included all items the loaded-on factor 1, in other words, those positive worded items, and results showed a one-factor structure with all four items also having factor loading greater than .30. In the third iteration, we used sample 2 to cross-validate iterations 1 and 2. Results of the EFA in this third iteration also replicated a one-factor structure with all items having factor loadings greater than .30 (Table 3).

\section{Confirmatory Factor Analyses (CFA)}

The one-factor structure of the four Job Satisfaction Brief Scale items was examined using structural equation modeling to confirm said internal structure. We used sample 3 for this first CFA. All fit indices can be considered very good, except the RMSEA, which was above the threshold of .08 (see table 4), and it can be considered mediocre (MacCallum et al., 1996). Modification indices were examined to improve the fit of the model. However, none reached the threshold value of 10, which is considered the minimum for the modifications to significantly change the overall model fit (Byrne, 2016). Nevertheless, Shi et al. (2021) and Kenny et al. (2014) recommend that researchers use caution when interpreting RMSEA for models with a small degree of freedom and rely more on SRMR and CFI; thus, since those fit indices were excellent, it was decided to probe the model with sample 4 to cross-validate the one-factor structure model. All fit indices obtained were better, including the RMSEA (Table 4), supporting the one-factor model of the Job Satisfaction Brief Scale. All factor loadings were greater than .70, except item 7 (Table 5).

Table 3

Exploratory factor analyses of the Job Satisfaction Brief Scale sample $1\left(n_{1}\right)$ and replication sample $2\left(n_{2}\right)$

\begin{tabular}{|c|c|c|c|c|c|c|c|}
\hline \multirow{4}{*}{ Item } & \multicolumn{3}{|c|}{ Sample 1 (n1) } & \multicolumn{2}{|c|}{ Sample $1\left(\mathrm{n}_{1}\right)$} & \multicolumn{2}{|c|}{ Sample $2\left(\mathrm{n}_{2}\right)$} \\
\hline & \multicolumn{3}{|c|}{$1^{\text {st }}$ Iteration } & \multicolumn{2}{|c|}{$2^{\text {nd }}$ Iteration } & \multicolumn{2}{|c|}{$3^{\text {rd }}$ Iteration } \\
\hline & \multicolumn{2}{|c|}{ Factor } & \multirow{2}{*}{$h^{2}$} & Factor & \multirow{2}{*}{$h^{2}$} & Factor & \multirow{2}{*}{$h^{2}$} \\
\hline & 1 & 2 & & 1 & & 1 & \\
\hline JS-1 & & .42 & .159 & $X$ & $x$ & $X$ & $x$ \\
\hline JS-2 & .62 & & .444 & .56 & .430 & .72 & .512 \\
\hline JS-3 & & .74 & .564 & $\bar{x}$ & $x$ & $\bar{x}$ & $x$ \\
\hline JS-4 & & .80 & .683 & $X$ & $X$ & $X$ & $X$ \\
\hline JS-5 & .74 & & .627 & .79 & .625 & .77 & .588 \\
\hline JS-6 & & .63 & .495 & $\bar{x}$ & $\mathrm{X}$ & $x$ & $X$ \\
\hline JS-7 & .62 & & .341 & .55 & .299 & .48 & .229 \\
\hline JS-8 & .78 & & .661 & .82 & .672 & .76 & .583 \\
\hline Eigen Value & 2.92 & 1.06 & & 2.03 & & 1.91 & \\
\hline \% Exp. Var. & 36.45 & 13.21 & & 50.63 & & 47.78 & \\
\hline KMO & .810 & & & .767 & & .763 & \\
\hline $\mathrm{X}^{2}(\mathrm{df})$ & $950.17^{*}(28$ & & & $451.96^{*}(6$ & & $392.95^{*}(6$ & \\
\hline
\end{tabular}

Note. $\mathrm{n}_{1}=358, \mathrm{n}_{2}=364 ;{ }^{*} \mathrm{p}<.01 ; \mathrm{df}=$ degree of freedom, $\mathrm{X}=$ Item not included in analysis. 
Table 4

Fit indices obtained by the Job Satisfaction Brief Scale in the sample 3 (n3) and sample $4\left(n_{4}\right)$

\begin{tabular}{lccccc}
\hline Model & $X^{2}(\mathrm{df})$ & SRMR & $\begin{array}{c}\text { RMSEA } \\
(90 \% \mathrm{CI})\end{array}$ & CFI & TLI \\
\hline Sample 3 $\left(\mathrm{n}_{3}\right)$ & & & & & \\
One-Factor & $9.225^{*}(2)$ & .023 & $.100(.042-.170)$ & .993 & .979 \\
Sample 4 $\left(\mathrm{n}_{4}\right)$ & & & & & \\
One-Factor & $4.025^{\mathrm{NS}}(2)$ & .012 & $.050(.000-.121)$ & .999 & .998 \\
\hline
\end{tabular}

Note. $\mathrm{n}_{3}=387, \mathrm{n}_{4}=382 ;{ }^{*} \mathrm{p}<.05, \mathrm{NS}=$ Not Significant; $\mathrm{CI}=$ Confidence Interval.

Table 5

Factor loadings obtained by the items of the Job Satisfaction Brief Scale in the base sample $3\left(n_{3}\right)$ and sample

\begin{tabular}{lccc}
$4(n 4)$. & & & \\
\hline Item & $\begin{array}{c}\text { Sample 3 }(\mathrm{n} 3) \\
\text { Factor Loading }\end{array}$ & $\begin{array}{c}\text { Sample } 4(\mathrm{n} 4) \\
\text { Factor Loading }\end{array}$ & $\begin{array}{c}\text { Total Sample } \\
(\mathrm{n}) \\
\text { Factor Loading }\end{array}$ \\
\hline JS-2 & .756 & .827 & .781 \\
JS-5 & .782 & .916 & .832 \\
JS-7 & .569 & .604 & .529 \\
JS-8 & .842 & .866 & .914 \\
\hline
\end{tabular}

Note. $\mathrm{n}_{3}=387, \mathrm{n}_{4}=382, \mathrm{n}_{\mathrm{T}}=1,491$.

\section{Convergent and Divergent Validity}

First, to evaluate the convergent validity of a reflective construct as job satisfaction, we checked that the average variance extracted (AVE) value of the four items of the Job Satisfaction Brief Scale were $\geq$ .50 , which indicates that the items converge or share a high proportion of the variance (Fornell \& Larcker, 1981). We calculated the AVE using the whole sample, and it was .61, well above the threshold of .50 . Therefore, the Job Satisfaction Brief Scale indicators share a high proportion of variance. We also estimated maximum share variance (MSV) and the average share variance (ASV) to establish divergent validity, and the results were .49 and .31, respectively. Since the values of the MSV and ASV were lower than the AVE, supporting the discriminant validity.

Convergent and discriminant validity were examined through the average variance extracted (AVE). This method indicates that the items converge or share a high proportion of the variance. The higher the value of the AVE, the lower the error variance.
The AVE value obtained for the four Job Satisfaction Brief Scale items was AVE $=.60$. For the AVE to be considered acceptable, this value must be equal to or greater than .50 (Fornell \& Bookstein, 1982; Fornell \& Larcker, 1981). On the other hand, for there to be evidence of divergent validity, the MSV and the ASV must be less than the value obtained from the AVE. The MSV and ASV values were .49 and .31, respectively, well below the AVE value.

Also, for convergent validity, the focal construct should be empirically relayed to theoretically linked constructs such that it retains its uniqueness but reflects the underlying similarities with those related constructs (Campbell \& Fiske, 1959). Job satisfaction is theoretically related to work engagement (e.g., Halbesleben, 2010; Molero Jurado et al., 2019; Orgambidez \& Extremera, 2020) and the professional efficacy subscale of the MBI-GS (e.g., Molero Jurado et al., 2019), and their correlations fluctuated between $r=$ $.458, p<.01$ and $r=.595, p<.01$ (see Table 6), which can be considered as moderate to large correlations (Cohen, 1988). On the other hand, job satisfaction is theoretically related inversely to the other two subscales of the MBI-GS (Molero Jurado et al., 2019), emotional exhaustion, and cynicism $(r=-.363, p<.01$ $\& r=-.270, p<.01)$, and turnover intention $(r=-.334$, $p<.01)$. Finally, job satisfaction is not supposed to be related to the social desirability and results shown, the relationship between them was near zero $(r=-$ $.030, p>.05)$.

\section{Reliability and Descriptive Statistics}

We estimated the mean, standard deviation, standard error of measurement, and 95\% confidence interval for the scores of the final version of the Job 
Satisfaction Brief Scale (see Table 7). Moreover, we estimated the reliability using Cronbach's alpha and McDonald's omega with their respective confidence interval, and all reliability coefficients were above .70 as suggested by some of the literature (e.g., DeVellis, 2017; Spector, 1992).

\section{Measurement Invariance}

We tested measurement invariance across participants from various groups, specifically gender (male/female), age (21-30/31-50/ $\geq 51)$, job position (managerial/non-managerial), type of organization (public/private), and type of contract (tenure/temporary). The one factor model of the Job Satisfaction Brief Scale was integrated into the configural invariance model, with the same pattern of fixed and free factor loadings. However, no equality restrictions were imposed on any parameter across groups. The configural invariance model fits the data well (see Table 8). This configural model was then used to compare against the more restrictive measurement invariance (i.e., weak measurement invariance) model that we examined next. The first more restrictive model, the weak invariance model, fit the data well (see Table 8) for all groups, except for the type of contract. Changes of CFI and RMSEA, when the weak invariance model is compared with the configural invariance model, were within acceptable values to all group comparisons, except for the type of contract, as mentioned before, that was higher than the established thresholds; therefore, we stopped measurement invariance testing for the type of contract. Nevertheless, these results indicate that the metric of factor scores was invariant across the other groups compared. In other words, the items used to estimate the factor loadings have the same meaning for the compared groups. The next restrictive model, the strong invariance model, also fits the data well (see Table 8).

The second more restrictive model, which constrained the factor loadings and item intercept to create the solid invariance model, resulted in strong invariance. This indicates that both factor loadings and item intercept are invariant between are groups compared. The last more restrictive model was inspected, which constrained the factor loadings, item intercept, and residual variances to produce the strict invariance model. The changes of the fit indices were above the thresholds for gender, age, and type of organization; however, job positions were within the recommended values. This suggests that average item score comparisons are valid across job positions but not for comparisons of the other groups tested.

\section{Table 6}

Correlation between observed and latent scores of the Job Satisfaction Brief Scale with other measures to establish convergent and divergent validity.

\begin{tabular}{lccccccccc}
\hline \multicolumn{1}{c}{ Scale } & JS & Vig & Ded & Abs & PE & EE & Cyn & TI & SD \\
\hline Job Satisfaction (JS) & 1 & $.50^{* *}$ & $.60^{* *}$ & $.50^{* *}$ & $.46^{* *}$ & $-.27^{* *}$ & $-.36^{* *}$ & $-.34^{* *}$ & -.03 \\
Vigor (Vig) & $.66^{* *}$ & 1 & $.80^{* *}$ & $.76^{* *}$ & $.30^{* *}$ & $-.43^{* *}$ & $-.46^{* *}$ & $-.43^{* *}$ & .01 \\
Dedication (Ded) & $.70^{* *}$ & $.97^{* *}$ & 1 & $.78^{* *}$ & $.36^{* *}$ & $-.32^{* *}$ & $-.41^{* *}$ & $-.39^{* *}$ & -.02 \\
Absorption (Abs) & $.66^{* *}$ & $.94^{* *}$ & $.88^{* *}$ & 1 & $.32^{* *}$ & $-.31^{* *}$ & $-.35^{* *}$ & $-.35^{* *}$ & -.03 \\
Professional Efficcy (PE) & $.63^{* *}$ & $.42^{* *}$ & $.45^{* *}$ & $.45^{* *}$ & 1 & $-.06^{*}$ & $-.15^{* *}$ & $-.17^{* *}$ & $-.08^{* *}$ \\
Emotional Exhaustion (EE) &.$- .40^{* *}$ & $-.53^{* *}$ & $-.37^{* *}$ & $-.41^{* *}$ & $-.18^{* *}$ & 1 & $.59^{* *}$ & $.47^{* *}$ & $-.10^{* *}$ \\
Cynicism (Cyn) & $-.59^{* *}$ & $-.59^{* *}$ & $-.52^{* *}$ & $-.50^{* *}$ & $-.42^{* *}$ & $.70^{* *}$ & 1 & $.49^{* *}$ & $-.12^{* *}$ \\
Turnover Intention (TI) & $-.47^{* *}$ & $-.53^{* *}$ & $-.44^{* *}$ & $-.45^{* *}$ & $-.25^{* *}$ & $.56^{* *}$ & $.62^{* *}$ & 1 & $-.13^{* *}$ \\
Social Desirability (SD) & -.04 & .01 & -.02 & -.04 & $-.11^{* *}$ & $-.12^{* *}$ & $-.08^{*}$ & $-.17^{* *}$ & 1 \\
\hline
\end{tabular}

Note. $\mathrm{n}=1,491 ; \mathrm{*} p<.05,{ }^{* *} \mathrm{p}<.01$; values above the diagonal represent the correlation between observed variables, while the values below the diagonal represent the correlation between latent variables. 
Table 7

Reliability and descriptive statistics of the Job Satisfaction

Brief Scale.

\begin{tabular}{cc}
\hline Statistic & Value \\
\hline Number of Items & 4 \\
Mean & 18.94 \\
Standard Deviation & 4.61 \\
Cronbach's Alpha (CI) & $.77(.750, .796)$ \\
McDonald's Omega (CI) & $.78(.754, .799)$ \\
Standard Error of Measurement & 2.21 \\
95\% Confidence Interval & \pm 4 \\
Possible Range of Scores & $4-20$ \\
\hline
\end{tabular}

Note. $\mathrm{n}=1,491 ; \mathrm{CI}=$ Confidence Interval.

\section{DISCUSSION}

This study aimed to develop and validate the Job Satisfaction Brief Scale. Results from the first EFA with sample 1 suggested a two-factor structure; however, when we examined the items and where they loaded, we found that positive wording items loaded on factor 1 and negative wording items loaded on factor 2 . These results suggested a false factorial distinction of the set of items (Schmitt \& Stults, 1985); therefore, we included those items that loaded on factor 1 in a second EFA with sample 1 and showed a onefactor structure. Thus, we perform a third EFA with these four items using this time sample 2 to examine if these results could be replicated. These four items of the Job Satisfaction Brief Scale loaded in one factor show this one-factor structure.

These four items were included in a CFA using sample 3. Fit indices were acceptable, except for the RMSEA, which was above the threshold of .08 and it is considered as a mediocre fit (MacCallum et al., 1996); therefore, we checked modification indices, but values were below the threshold of 10, which would not add a significant change to fit in-dices (Byrne, 2016). Moreover, since the interpretation of the RMSEA fit index is affected by a small degree of freedom (e.g., Kenny et al., 2014; Shi et al., 2021), we rely more on SRMR and CFI, which are not affected by small degrees of freedom. We performed another CFA with sample 4, and results showed excellent fit indices of the Job Satisfaction Brief Scale, including the RMSEA. Thus, results from EFA's and CFA's support the one-factor structure of the newly developed scale.
To establish convergent and divergent validity of the Job Satisfaction Brief Scale, first, we calculated the AVE, MSV, and ASV. The AVE value was more significant than the MSV and ASV values, supporting the convergent and divergent validity of the scale, as authors suggest (Fornell \& Bookstein, 1982; Fornell \& Larcker, 1981). Moreover, observed and latent scores' correlation directions of the Job Satisfaction Brief Scale and other measures were hypothesized. Job satisfaction scores correlated positively to the three dimensions of work engagement and professional efficacy subscale of the MBI-GS, supporting the convergent validity of the job Satisfaction Brief Scale as stated by some of the literature (e.g., Choi et al., 2020; Karanika-Murray et al., 2015; Panthee et al., 2014). On the other hand, Job satisfaction scores correlated negatively to the emotional exhaustion and cynicism of the MBI-GS, and turnover intention, supporting divergent validity of the newly developed scale as the literature suggested (e.g., Gebregziabher et al., 2020; Maslach et al., 2001; Maslach, \& Schaufeli, 1993; Riggar et al., 1984; Zedeck et al., 1988). Meanwhile, job satisfaction scores from the Job Satisfaction Brief Scale did not correlate to social desirability, and such correlation coefficient was near zero, also supporting the divergent validity of the scale as suggested by some of the literature (e.g., Ganster et al., 1983; Moorman \& Podsakoff, 1992).

The present study provides insight on measurement invariances of the Job Satisfaction Brief Scale across gender, age, job position, type of organization, and type of contract. We tested the measurement invariances of the Job Satisfaction Brief Scale among employees of different organizations in Puerto Rico. Exploration on the first two levels revealed metric or factor loading invariance (i.e., weak measurement invariance) and scalar invariance (i.e., strong measurement invariance) of the one-factor model across gender, age, job position, and type of organization. Metric invariance is essential to ensure the measure across multiple groups is considered on the same scale, or the factors are measured in the same way in all groups (Vandenberg and Lance, 2000; Meredith \& Teresi, 2006; Wang \& Wang, 2012). Scalar invariance refers to the item intercept being invariant across multiple groups in the present study. This indicates that none of the groups respond systematically 
higher or lower to the items of scales than other groups (Meredith \& Teresi, 2006; Vandenberg \& Lance, 2000; Wang \& Wang, 2012). The present study met both invariance requirements. These results confirm that the compared groups had an equivalent understanding of each of the four items in the measure, which is an essential prerequisite for making a meaningful comparison between groups on job satisfaction, except for the type of contract that was not even able to establish the metric invariance. Researchers have argued that error variance invariance (i.e., strict measurement invariance) is not required for substantive analyses in many disciplines, and such invariance is considered unnecessary (Wang \& Wang, 2012). However, error variance invariance is crucial when items' reliability across groups is of concern. This is because error variance invariance is considered invariance of item reliabilities across groups (Schmitt et al., 1984), given that the factor variances are invariant across groups (Vandenberg \& Lance, 2000). The current finding on the Job Satisfaction Brief Scale across job positions met the strict measurement invariance criterion and outperformed the psychometric standards in invariance testing.

Table 8

Measurement invariance of the Job Satisfaction Brief Scale by gender, age, job position, type of organization, and type of contract.

\begin{tabular}{llllll}
\hline Model & $X^{2}(\mathrm{df})$ & CFI & RMSEA $(90 \% \mathrm{CI})$ & $\begin{array}{l}\text { Model of } \\
\text { Reference }\end{array}$ & $\Delta X^{2}$ \\
\hline
\end{tabular}

\section{Multigroup analysis by gender (male/female)}

$\begin{array}{llll}\text { 1: Configural } & 10.621^{*}(4) & .992 & .048(.060-.075) \\ \text { 2: Metric } & 18.274^{*}(7) & .982 & .048(.065-.070) \\ \text { 3: Scalar } & 21.906^{*}(10) & .986 & .041(.055-.068) \\ \text { 4: Residual } & 36.318^{*}(11) & .970 & .057(.051-.064)\end{array}$

Multigroup analysis by age (21-30 /31-50 / $\geq 51)$

$\begin{array}{lccc}\text { 1: Configural } & 10.954^{\mathrm{NS}}(6) & .994 & .041(.000-.079) \\ \text { 2: Metric } & 10.684^{\mathrm{NS}}(12) & 1.000 & .000(.000-.042) \\ \text { 3: Scalar } & 16.385^{\mathrm{NS}}(18) & 1.000 & .000(.000-.036) \\ \text { 4: Residual } & 22.573^{\mathrm{NS}}(20) & .997 & .016(.000-.043)\end{array}$

Multigroup analysis by job position (managerial/non-managerial)

$\begin{array}{lccc}\text { 1: Configural } & 11.542^{*}(4) & .991 & .051(.018-.087) \\ \text { 2: Metric } & 10.613^{\mathrm{NS}}(7) & .996 & .027(.000-.057) \\ \text { 3: Scalar } & 14.798^{\mathrm{NS}}(10) & .994 & .026(.000-.052) \\ \text { 4: Residual } & 13.270^{\mathrm{NS}}(11) & .997 & .017(.000-.044) \\ \text { Multigroup analysis by type of organization (public/private) }\end{array}$

$\begin{array}{lccc}\text { 1: Configural } & 10.182^{*}(4) & .993 & .046(.010-.082) \\ \text { 2: Metric } & 16.150^{*}(7) & .990 & .042(.015-.070) \\ \text { 3: Scalar } & 20.330^{*}(10) & .988 & .038(.012-.061) \\ \text { 4: Residual } & 49.107^{*}(11) & .957 & .069(.050-.089)\end{array}$

Multigroup analysis by type of contract (tenure/temporary)

$\begin{array}{lccc}\text { 1: Configural } & 12.190^{*}(4) & .991 & .053(.020-.088) \\ \text { 2: Metric } & 27.065^{*}(7) & .977 & .062(.039-.088) \\ \text { 3: Scalar } & 29.983^{*}(10) & .977 & .052(.031-.074) \\ \text { 4: Residual } & 23.986^{*}(11) & .985 & .040(.018-.062)\end{array}$

Note. ${ }^{*} \mathrm{p}<.05, \mathrm{df}=$ degree of freedom, NS = Not Significant.

$\begin{array}{cccc}---- & ---- & ---- & ---- \\ 1 & +7.653 & -.010 & .000 \\ 2 & +3.632 & +.004 & -.007 \\ 3 & +14.412 & -.016 & +.016\end{array}$

$\begin{array}{cccc} & & & \\ ---- & ---- & ---- & ---- \\ 1 & -0.270 & +.006 & -.041 \\ 2 & +5.701 & .000 & .000 \\ 3 & +6.188 & -.003 & +.016\end{array}$


Finally, the scale obtained satisfactory reliability coefficients using Cronbach's alpha and McDonald's omega. This serves as a useful description as an indication of the degree of coherence of the constituent parts of a whole; in other words, how the four items of the Job Satisfaction Brief Scale relate to each other (McCrae et al., 2011). Also, descriptive statistics were calculated, such as mean, standard deviation, to facilitate researchers to compare their results with the sample use as reference.

In terms of reliability, the coefficients and levels achieved are satisfactory in a broad sense, especially when taking into account the interplay between the small number of items on the scale, the sample size, and the value reached (Ponterotto \& Ruckdeschel, 2007). Because the coefficients are not high (i.e., .85 or more), the possibility of measurement error can still be considered high. These levels do not indicate using the Job Satisfaction Brief Scale for all uses, but primarily for group applications and where decisions on individual subjects are not needed (Ponterotto \& Ruckdeschel, 2007). Given the similarity of the coefficients $\alpha$ and $\omega$, it is presumed that any differences between the factorial loadings were trivial (Hayes \& Coutts, 2020), and did not have a significant effect on the distance between one coefficient and the other. The degree of equality of the factorial loadings of the items is frequently connected with this distance, a condition known as tau-equivalence to validate the coefficient (Green \& Yang, 2009; Hayes \& Coutts, 2020). This closeness implies that the assessment of internal consistency may be done well with the coefficient, without the need for SEM modeling or SEM modeling methodologies to estimate the coefficient (RosarioHernández et al., 2021).

\section{Limitations and Recommendations}

The current study has several shortcomings that must be kept in mind when interpreting the results. First, the population representativeness is not guaranteed, because the convenient sample selection of the workers did not corroborate the population similarity of employees in organizations in Puerto Rico. However, the sample was sufficiently large and heterogenous. Second, the stability of the scores was not evaluated for reliability; to complete the evaluation of this element, it should investigate the score's reproducibility over time using a test-retest approach.

\section{CONCLUSIONS}

The final version of the Job Satisfaction Brief Scale (Appendix 1) is comprised of a four-items that measures a unidimensional construct of job satisfaction in general. Convergent and divergent validity of the scale was supported by correlation between observed and latent variables as hypothesized. Measurement invariance of the scale was supported for gender, age, job position, and type of organization; in other words, comparison among these groups are appropriated. Finally, the Job Satisfaction Brief Scale has satisfactory reliability coefficients.

\section{REFERENCES}

Begley, T.M. \& Czajka, J.M. (1993). Panel analysis of the moderating effects of commitment on job satisfaction, intent to quit, and health following organizational change. Journal of Applied Psychology, 78, 552-556.

Bright, L. (2021). Does perceptions of organizational prestige mediate the relationship between public service motivation, job satisfaction, and the turnover intentions of federal employees? Public Personnel Management, 50 (3), 408-429. https://doi.org/10.1177\%2F0091026020952818

Browne, M. W. \& Cudeck, R. (1989). Single sample cross-validation indices for covariance structures. Multivariate Behavioral Research, 24, 445-455. https://doi.org/10.1207/s15327906mbr2404_4

Byrne, B. M. (2016). Structural equation modeling with AMOS: Basic concepts, applications, and programming. New York, NY: Routledge.

Campbell, D. T., \& Fiske, D. W. (1959). Convergent and discriminant validation by the multitrait-multimethod matrix. Psychological Bulletin, 56(2), 81-105. https://doi.org/10.1037/h0046016

Cammann, C., Fichman, M., Jenkins, D., \& Klesh, J. (1979). The Michigan Organizational Assessment Questionnaire. Unpublished manuscript, University of Michigan, Ann Harbor.

Carsten, J.M. \& Spector, P.E. (1987). Unemployment, job satisfaction, and employee turnover: A meta-analytic test of the Muchinski model. Journal of Applied Psychology, 72, 374-381.

Choi, M., Suh, C., Choi, S. P., Lee, C. K., \& Son, B. C. (2020). Validation of the Work Engagement Scale-3, used in the 5th Korean Working Conditions Survey. Annals of occupational and environmental medicine, 32, e27. https://doi.org/10.35371/aoem.2020.32.e27

Chen, F. F. (2007). Sensitivity of goodness of fit indexes to lack of measurement invariance. Structural Equation Modeling, 14, 464-504. https://psycnet.apa.org/doi/10.1080/10705510701301834 
Dawis, R.V. (2004). Job satisfaction. In J.C. Thomas (Ed.), Comprehensive handbook of psychological assessment (Vol. 4, pp. 470481). Hoboken, NJ: Wiley.

DeVellis, R. F. (2017). Scale Development: Theory and Applications. Thousand Oaks, CA: SAGE Publications.

Ekhsan, M. (2019). The influence job satisfaction and organizational commitment on employee turnover intention. Journal of Business Management in Account, 1, 48-55.

Fornell, C., \& Bookstein, F. L. (1982). Two structural equation models: LISREL and PLS applied to consumer exit-voice theory. Journal of Marketing Research, 19(4), 440-452. https://doi.org/10.2307/3151718

Fornell, C., \& Larcker, D. F. (1981). Evaluating structural equation models with unobservable variables and measurement error. Journal of Marketing Research, 18(1), 39-50. https://doi.org/10.2307/3151312

Ganster, D.C., Hennessey, H.W., \& Luthans, F. (1983). Social desirability response effects: Three alternative models. Academy of Management Journal, 26, 321-331.

Gebregziabher, D., Berhanie, E., Berihu, H, Belstie, A., \& Teklay, G. (2020). The relationship between job satisfaction and turnover intention among nurses in Axum comprehensive and specialized hospital Tigray, Ethipia. BMC Nursing, 19, 79. https://doi.org/10.1186/s12912-020-00468-0

Green, S.B. \& Yang, Y. (2009). Reliability of Summed Item Scores Using Structural Equation Modeling: An Alternative to Coefficient Alpha. Psychometrika, 74, 155-167. https://doi.org/10.1007/s11336-008-9099-3

Hackman, J. R., \& Oldham, G. R. (1975). Development of the Job Diagnostic Survey. Journal of Applied Psychology, 60(2), 159170. https://doi.org/10.1037/h0076546

Hair, J.F., Black, W.C., Babin, B.J., \& Anderson, R.E. (2019). Multivariate data analysis. Hampshire, UK: Cengage.

Halbesleben, J. R. B. (2010). A meta-analysis of work engagement: Relationships with burnout, demands, resources, and consequences. In A. B. Bakker \& M. P. Leiter (Eds.), Work engagement: A handbook of essential theory and research (pp. 102-117). New York: Psychology Press.

Hankins, M. (2008). The factor structure of the twelve item General Health Questionnaire (GHQ-12): The result of negative phrasing? Clinical Practice and Epidemiology in Mental Health, 4, Article 10. https://doi.org/10.1186/1745-0179-4-10

Häusser, J.A., Mojzisch, A., Niesel, M., \& Schulz-Hardt, S. (2010). Ten years on: A review of recent research on the Job DemandControl (-Support) model and psychological well-being. Work $\mathcal{E}$ Stress, 24(1), 1-35. https://psycnet.apa.org/doi/10.1080/02678371003683747

Hayes, A. F. \& Coutts, J. J. (2020). Use omega rather than cronbach's alpha for estimating reliability. Communication Methods and Measures, 14(1), 1-24. https://doi.org/10.1080/19312458.2020.1718629

Hu, L.-t., \& Bentler, P. M. (1999). Cutoff criteria for fit indexes in covariance structure analysis: Conventional criteria versus new alternatives. Structural Equation Modeling, 6(1), 1-55. https://doi.org/10.1080/10705519909540118

Hulin, C.L \& Judge, T.A. (2003). Job attitudes. In W.C. Borman, D.R. Ilgen, \& R.J. Klimoski (Eds.), Handbook of psychology (Vol. 12): Industrial and organizational psychology (pp. 255-276). Hobeken, NJ: Wiley.

Ironson, G.H., Smith, P.C., Brannick, M.T., Gibson, W.M., \& Paul, K.B. (1989). Constitution of a Job in General Scale: A comparison of global, composite, and specific measures. Journal of Applied Psychology, 74(2), 193-200. http://doi.org/10.1037/00219010.74.2.193

Johns, G. (1997). Contemporary research on absence from work: Correlates, causes, and consequences. In C.L. Cooper \& I.T. Robertson (Eds.), International review of industrial and organizational psychology (Vol. 12, pp.115-173). Chichester: Wiley.

Judge, T.A., Thoresen, C.J., Bono, J.E., \& Patton, G.K. (2001). The job satisfaction-job performance relationship: A qualitative and quantitative review. Psychological Bulletin, 127, 376-407.

Karanika-Murray, M., Duncan, N., Pontes, H.M., \& Griffiths, M.D. (2015). Organizational identification, work engagement, and job satisfaction. Journal of Managerial Psychology, 30(8), 10191033.

Kenny, D. A., Kaniskan, B., \& McCoach, D. B. (2015). The performance of RMSEA in models with small degrees of freedom. Sociological Methods \& Research, 44(3), 486-507. https://doi.org/10.1177/0049124114543236

Kline, P. (1994). An easy guide to factor analysis. London, UK: Routledge.

Kline, R.B. (2016). Principles and practice of structural equation modeling. New York, NY: The Guilford Press.

Lambert, E., Lynne Hogan, N., \& Barton, S. (2001). The impact of job satisfaction on turnover intent: A test of a structural measurement model using a national sample of workers. The Social Science Journal, 38(2), 233-250.

Lee, R.T. \& Ashforth, B.E. (1993). A further examination of managerial burnout: Toward an integrated model. Journal of Organizational Behavior, 14, 3-20.

Li, C.H. (2016a). Confirmatory factor analysis with ordinal data: Comparing robust maximum likelihood and diagonally weighted least squares. Behavioral Research Methods, 48(3), 936949. https://doi.org/10.3758/s13428-015-0619-7

Li, C.-H. (2016b). The performance of ML, DWLS, and ULS estimation with robust corrections in structural equation models with ordinal variables. Psychological Methods, 21(3), 369-387. https://doi.org/10.1037/met0000093

Lum, L., Kervin, J., Clark, K., Reid, F., \& Sirola, W. (1998). Explaining nursing turnover intent: Job satisfaction, pay satisfaction, or organizational commitment? Journal of Organizational Behavior, 19(3), 305-320.

MacCallum, R.C., Browne, M.W., \& Sugawara, H.M. (1996). Power analysis and determination of sample size for covariance structure modeling. Psychological Methods, 1, 130-139. https://doi.org/10.1037/1082-989X.1.2.130 
Marsh, H. W., Balla, J. R., \& Hau, K. T. (1996). An Evaluation of Incremental Fit Indexes: A Clarification of Mathematical and Empirical Properties. In G. A. Marcoulides, \& R. E. Schumacker (Eds.), Advanced Structural Equation Modeling Techniques (pp. 315-353). Mahwah, NJ: Lawrence Erlbaum.

Martínez-Alvarado, L.Y., Rosario-Hernández, E., \& RoviraMillán, L.V. (2017). La relación entre la inseguridad laboral y el bienestar psicológico en una muestra de asistentes de vuelo: El papel moderador del engagement en el trabajo. Ciencias de la Conducta, 32(1), 99-127.

Maslach, C., Jackson, S. E., and Leiter, M. P. (1996). Maslach Burnout Inventory manual. Palo Alto, CA: Consulting Psychologists Press.

Maslach, C., \& Schaufeli, W. (1993) Historical and conceptual development of burnout. In Schaufeli, W., Maslach, C., \& Marek, T. (Ed.), Professional Burnout: Recent Developments in Theory and Practice. Washington, DC: Taylor \& Francis.

McCrae, R. R., Kurtz, J. E., Yamagata, S., \& Terracciano, A. (2011). Internal consistency, retest reliability, and their implications for personality scale validity. Personality and Social Psychology Review, 15(1), 28-50. https://doi.org/10.1177/1088868310366253

Meredith, W., \& Teresi, J. A. (2006). An Essay on Measurement and Factorial Invariance. Medical Care, 44(11, Suppl 3), S69S77. https://doi.org/10.1097/01.mlr.0000245438.73837.89

Michaels, C. E., \& Spector, P. E. (1982). Causes of employee turnover: A test of the Mobley, Griffeth, Hand, and Meglino model. Journal of Applied Psychology, 67(1), 53-59. http://dx.doi.org/10.1037/0021-9010.67.1.53

Mobley, W. H. (1977). Intermediate linkages in the relationship between job satisfaction and employee turnover. Journal of Applied Psychology, 62(2), 237-240.

Molero-Jurado, M., Pérez-Fuentes, M., Atria, L., Oropesa-Ruiz, N.F., Gázquez-Linares, J.J. (2019). Burnout, perceived efficacy, and job satisfaction: Perception of the educational context in high school teachers. BioMed Research International, 2019, 1021408, 10 pages. https://doi.org/10.1155/2019/1021408

Moorman, R.H. \& Podsakoff, P.M. (1992). A meta-analytic review and empirical test of the potential confounding effects of social desirability response sets in organizational behaviour research. Journal of Occupational and Organizational Psychology, $65,131-149$.

Muchinsky, P.M. (2012). Psychology applied to work: An introduction to industrial and organizational psychology. Summerfield, NC: Hypergraphics Press, Inc.

Muthén, L. K., and Muthén, B. O. (1998-2012). Mplus User's Guide. Los Angeles, CA: Muthén \& Muthén.

Orgambidez, A. \& Extremera, N. (2020). Understanding the link between work engagement and job satisfaction: Do role stressors underlie this relationship? Scandinavian Journal of Psychology, 61(30), 443-449. https://doi.org/10.1111/sjop.12613

Panthee, B., Shimazu, A., Kawakami, N. (2014). Validation of Nepalese version of Utrecht Work Engagement Scale. Journal of Occupational Health, 56(6), 421-429.
Ponterotto, J. G. \& Ruckdeschel, D. E. (2007). An overview of coefficientalpha and a reliability matrix for estimating adequacy of internal consistencycoefficients with psychological research measures. Perception and Motor Skills, 105, 997-1014. https://doi.org/10.2466/pms.105.3.997-1014

Riggar, T.F., Godley, S.H., \& Hafer, M. (1984). Burnout and job satisfaction in rehabilitation administrators and direct service providers. Rehabilitation Counseling Bulletin, 27, 151-160.

Rigdon, E. E. (1995). A necessary and sufficient identification rule for structural models estimated in practice. Multivariate Behavioral Research, 30(3), 359-383. https://doi.org/10.1207/s15327906mbr3003_4

Rodríguez-Montalbán, R., Martínez-Lugo, M.E., Andújar-Rojas, C.A. (2011, marzo). Análisis de las Propiedades de la Escala de Engagement en el Trabajo de Utrecht en un grupo de empleados/as en Puerto Rico. Ponencia presentada en el Primer Congreso de Psicología Industrial Organizacional de Puerto Rico: "Acciones Estratégicas para la Gestión del Capital Humano," Ponce, Puerto Rico.

Rosario-Hernández, E. \& Rovira-Millán, L.V. (2002). Desarrollo y validación de una escala para medir actitudes hacia el retiro. Revista Puertorriqueña de Psicología, 13, 45-60.

Rosario-Hernández, E. \& Rovira-Millán, L.V. (2018). Development and validation of the Turnover Intention Scale. Unpublished manuscript.

Rosario-Hernández, E., Rovira Millán, L.V., \& Merino-Soto, C. (2021). Review of the Internal Structure, Psychometric Properties, and Measurement Invariance of the Work-Related Rumination Scale - Spanish Version. Frontiers in Psychology, 12. https://www.frontiersin.org/article/10.3389/fpsyg.2021.774472

Rosario-Hernández, E., Rovira Millán, L.V., Vélez Ramos, J., Cruz, M., Vélez, E., Torres, G., Alomar, G., Caldera, J., Santiago, M., Arroyo, Y., Sánchez, I., \& Rodríguez, N. (2018). Effect of the exposure to workplace bullying on turnover intention and the mediating role of job satisfaction, work engagement, and burnout. Revista Interamericana de Psicología Ocupacional, 37(1), 26-51. https://doi.org/10.21772/ripo.v37n1a03

Rosseel, Y. (2012). lavaan: An R Package for Structural Equation Modeling. Journal of Statistical Software, 48(2), 1-36. https://www.jstatsoft.org/v48/i02/

Schaufeli, W., \& Bakker, A. (2003). Utrecht work engagement scale: Preliminary manual. Utrecht: Occupational Health Psychology Unit, Utrecht University.

Schaufeli, W.B., Salanova, M., González-Romá, V., Bakker, A.B. (2002). The measurement of engagement and burnout: A confirmative analytic approach. Journal of Happiness Studies, 3, 792. https://doi.org/10.1023/A:1015630930326

Schmitt, N., \& Stults, D. M. (1985). Factors defined by negatively keyed items: The results of careless respondents? Applied Psychological Measurement, 9, 367-373. https://doi.org/10.1177/014662168500900405

Shi, D., DiStefano, C., Maydeu-Olivares, A., \& Lee, T. (2021). Evaluating SEM Model Fit with Small Degrees of Freedom. Multivariate behavioral research, 1-36. 
https://doi.org/10.1080/00273171.2020.1868965

Smith, P.C., Kendall, L.M., \& Hulin, C.L. (1969). Measurement of job satisfaction in work and retirement. Chicago: Rand McNally.

Spector, P. E. (1985). Measurement of human services staff satisfaction: Development of the Job Satisfaction Survey. American Journal of Community Psychology, 13, 693-713.

Spector, P. E. (1992). Summated rating scale construction: An introduction. Newbury Park, CA: SAGE Publications.

Spector, P. E. (1997). Job satisfaction: Application, assessment, causes, and consequences. Thousand Oaks, CA: SAGE Publications.

Spector, P. E., Dwyer, D. J., \& Jex, S. M. (1988). Relation of job stressors to affective, health, and performance outcomes: A comparison of multiple data sources. Journal of Applied Psychology, 73(1), 11-19. http://dx.doi.org/10.1037/00219010.73.1.11

Vandenberg, R. J., \& Lance, C. E. (2000). A review and synthesis of the measurement invariance literature: Suggestions, practices, and recommendations for organizational research. Organizational Research Methods, 3(1), 4-69. https://doi.org/10.1177/109442810031002

van der Doef, M. \& Maes, S. (1999). The job demand-control (support) model and psychological well-being: A review of 20 years of empirical research. Work $\mathcal{E}$ Stress, 13(2), 87-114. https://doi.org/10.1080/026783799296084

Wall, T.D. (1972). Overall job satisfaction in relation to 'social desirability', age, length of employment and social class. British Journal of Social and Clinical Psychology, 11(1), 79-81. https://doi.org/10.1111/j.2044-8260.1972.tb00782.x

Wang, J. \& Wang, X. (2012). Structural Equation Modeling Applications Using Mplus. Chichester: John Wiley \& Sons Ltd. https://doi.org/10.1002/9781118356258

Weiss, D.J., Dawis, R.V., England, G.W., \& Lofquist, L.H. (1967). Manual for the Minnesota Satisfaction Questionnaire (Minnesota Studies in Vocational Rehabilitation, No. 22). University of Minnesota, Minneapolis.

https:/vpr.psych.umn.edu/sites/vpr.umn.edu/files/files/monograph_xxii_-_manual_for_the_mn_satisfaction_questionnaire.pdf

Zedeck, S., Maslach, C., Mosier, K., \& Skitka, L. (1988). Affective response to work and quality of family life: Employee and spouse perspectives. Journal of Social Behavior and Personality, 3(4), 135-157.

Zhang, T. \& Li, B. (2020). Job crafting and turnover intention: The mediating role of work engagement and job satisfaction. Social Behavior and Personality, 48(2), e8759.

https://doi.org/10.2224/sbp.8759

\section{Obra bajo licencia de Creative Commons Atribución 4.0 Internacional (CC BY 4.0).} (C) 2022 Autores. 


\begin{tabular}{|c|c|c|c|c|c|c|c|c|c|c|}
\hline & $\begin{array}{r}\mathrm{E} \\
\text { Autore }\end{array}$ & $\begin{array}{l}\text { Cala BreV } \\
\text { Ernesto Rosario-Hern }\end{array}$ & $\begin{array}{l}\text { de Sat } \\
\text { dez, Lillian V } \\
\text { echos Reserv }\end{array}$ & & & & $\begin{array}{l}\text { La } \\
\text { fael A }\end{array}$ & $\begin{array}{l}\text { ral } \\
\text { co Ror }\end{array}$ & & \\
\hline & $\begin{array}{l}\text { TRUCCIOI } \\
\text { con detenim } \\
\text { d siente acer } \\
\text { respuestas ci } \\
\text { erdo con el c } \\
\text { echo de cada } \\
\text { repasar sus re } \\
\text { o, conteste h } \\
\text { érico: }\end{array}$ & $\begin{array}{l}\text { ES: } \\
\text { ento cada una de la } \\
\text { a de su trabajo e in } \\
\text { culando en el núm } \\
\text { ntenido de las asev } \\
\text { severación. Trate } \\
\text { spuestas. Recuerde } \\
\text { nestamente cada as }\end{array}$ & $\begin{array}{l}\text { siguientes a } \\
\text { dique cuán de } \\
\text { ro que aproxi } \\
\text { eraciones en } \\
\text { de contestar t } \\
\text { que no hay c } \\
\text { everación. C }\end{array}$ & $\begin{array}{l}\text { adar } \\
\text { cont } \\
\text { as la } \\
\text { testa }\end{array}$ & D & & $\begin{array}{l}\text { cuales } \\
\text { ed con } \\
\text { ja cuá } \\
\text { rico qu } \\
\text { iones } \\
\text { rectas } \\
\text { lo con }\end{array}$ & $\begin{array}{l}\text { lacio } \\
\text { mism } \\
\text { stá us } \\
\text { prov } \\
\text { mitir } \\
\text { correc } \\
\text { guien }\end{array}$ & $\begin{array}{l}\text { nan a } \\
\text { as. Ma } \\
\text { ted de } \\
\text { ee al la } \\
\text { ningur } \\
\text { tas; p } \\
\text { te con }\end{array}$ & \\
\hline & $\begin{array}{l}\text { almente en } \\
\text { esacuerdo } \\
1 \\
\end{array}$ & $\begin{array}{c}\text { Moderadamente } \\
\text { en Desacuerdo } \\
2 \\
\end{array}$ & $\begin{array}{c}\text { Algo en De- } \\
\text { sacuerdo } \\
3 \\
\end{array}$ & & & & $\begin{array}{r}\text { oderad } \\
\text { en Acu } \\
5 \\
\end{array}$ & & $\begin{array}{l}\text { Total } \\
\text { en Ac }\end{array}$ & ente \\
\hline 1. & Me siento si & tisfecho con mi tra & ajo. & 1 & & ? & 3 & 4 & 5 & 6 \\
\hline 2. & $\begin{array}{l}\text { Me siento fe } \\
\text { bajo. }\end{array}$ & liz en el desempeñ & de mi tra- & 1 & te & & 3 & 4 & 5 & 6 \\
\hline 3. & $\begin{array}{l}\text { Me gusta } m \\
\text { con lo que } 1\end{array}$ & $\begin{array}{l}\text { trabajo más en con } \\
\text { s gusta a mis comp }\end{array}$ & $\begin{array}{l}\text { paración } \\
\text { añeros. }\end{array}$ & 1 & & ? & 3 & 4 & 5 & 6 \\
\hline 4. & Me disfruto & el trabajo que realiz & & 1 & & & 3 & 4 & 5 & 6 \\
\hline
\end{tabular}

Nota. Investigadores interesados en utilizar la Escala Breve de Satisfacción Laboral, favor de escribir al siguiente correo electrónico: erosario@psm.edu 